\title{
Accelerating Professional Socialization With an Undergraduate Proseminar Course
}

\author{
Carrie Anne Platt $\odot$
}

Keywords: first-year experience, proseminar, professional socialization, transitions

\begin{abstract}
Guiding students on their professional paths, from selecting a major to pursuing a particular career after graduation, can be a significant challenge for faculty and program leaders. Students, particularly those in broad fields like Communication, rarely know what the major involves, or how their studies will translate into a meaningful career. This uncertainty makes it harder for students to see connections between their coursework, campus resources, and extracurricular activities, a disconnect that impacts engagement, academic performance, and retention. In this best practices article, I explain how an undergraduate proseminar can accelerate professional socialization and help students develop more integrated perspectives on their college experience. By identifying possible careers early in their education and discussing how different courses, resources, and activities can aid them in pursuing those professions, students will be better able to navigate the challenges and opportunities of college.
\end{abstract}

Contemporary colleges and universities offer an array of coursework, extracurricular activities, and campus resources to aid students in the pursuit of their professional goals. Yet research on student perceptions and behaviors reveals low levels of engagement with these opportunities (National Survey of Student Engagement, 2018), as well as high levels of uncertainty regarding professional goals. In fact, nearly one in three students change their major during the first 3 years of college (U.S. Department of Education, 2017), suggesting that many students do not find their professional identity until late in their undergraduate programs. Instructional communication scholarship has helped us understand this uncertainty as part of a broader challenge that students face in redefining themselves and their interests while trying to integrate into new academic cultures (Smith, Carmack, \& Titsworth, 2006). It has also 
shown how specific pedagogical interventions at the start of an academic program can aid students in working through these challenges (Breslin \& Sharpe, 2018; Reynolds \& Sellnow, 2015).

Delays in professional socialization contribute to a perceived disconnect between different aspects of the college experience from the student perspective. This disconnect has far-reaching implications for both students and institutions of higher education. When students are unsure of their professional goals, they may struggle to see the value of their coursework, forgo involvement opportunities, and feel a sense of disconnect from others in their major, all factors that negatively impact academic performance and persistence (Conley, 2008; O'Keeffe, 2013). My proposed intervention is an undergraduate proseminar course, offered in the first semester of the students' major, that focuses on helping students develop their professional identities earlier. By accelerating professional socialization, students will be better able to see how the coursework they are taking, the extracurricular activities they are involved in, and the networks they are building all work together as crucial steps in the path toward their goals. In this essay, I present best practices for structuring and assessing this type of course.

A proseminar course can be used by anyone who wants to help new students integrate into their department, explore career options, forge connections with peers and faculty, and develop a compass for navigating educational opportunities both inside and outside of the classroom. The course follows the model of first-year experience programs, which provide a framework for students to identify transformative opportunities at their institution (Breslin \& Sharpe, 2018), and graduate proseminars, which acquaint students with the key practices, people, and norms of the field at the start of their course of study. These elements can be essential to both academic and professional success (Weidman \& Stein, 2003). I developed the course in response to student feedback solicited by our curriculum committeewhich indicated a need for this information at the beginning of the program-and the discontinuation of a university-wide first-year experience course. I believed that a program-specific undergraduate proseminar would help students transition successfully into our program, improve department retention, and increase participation in relevant extracurricular activities.

\section{Navigating New Academic Cultures}

Scholarship in instructional Communication has demonstrated the value of culture-based theories for understanding academic transitions, as students must learn how to navigate the cultures of both college and their major program. Martin (2011) used cross-cultural adaptation theory to investigate how students' progress through the stress-adaptation-growth process affects retention. He found that students who spend more time in the stress portion of the cycle are more likely to leave college than peers who adapt more quickly to their new academic culture (Martin, 2011). Sollitto et al. (2013) used organizational socialization theory to highlight the role social ties can play in a student's sense of academic integration in college. These theories help us anticipate potential obstacles to academic integration and develop interventions that help students navigate new academic cultures.

Within the context of higher education, growth often coincides with the encounter stage of the organizational socialization process (Miller \& Jablin, 1991), when students compare their experiences with their prior expectations and work to reconcile any differences. Adaptation is one outcome of the metamorphosis stage, during which students start to identify as Communication majors and make choices in line with that identification. We can design proseminar courses that will accelerate students' 
passage into the growth and adaptation portions of the cross-cultural adaption process through more proactive facilitation of the encounter stage.

This facilitation matters because the curricular structure in most higher education institutions slows the movement from encounter to metamorphosis, with specialized coursework and experiential opportunities like internships occurring in the junior or senior year. Like many departments, our firstyear curriculum consists of general education courses and survey courses in the discipline. Students complete a 19-credit sequence of general Communication courses before splitting up into the four majors we offer. Before the development of our proseminar, it took almost two years of coursework before students knew what made their major - and the work within the profession they were pursuingdistinct. The purpose of the proseminar is to accelerate this socialization process. By learning more about our programs and possible career options at the very start of their college experience, and building stronger connections with faculty and peers, students are better able to navigate both the opportunities and challenges they will encounter in college.

My proseminar course differs from other initiatives meant to socialize students into academic and professional communities in meaningful ways. Universities spend a significant amount of time and effort socializing first-year students to college through orientation and first-semester activities, but limited connections are made between the resources highlighted and specific academic programs. Career and advising services assist upper-division students with searching for internships and postgraduation jobs, but these services frequently rely on students having a strong sense of their professional goals and often remain disconnected from coursework and extracurricular opportunities. While most Communication programs offer exploratory courses that introduce students to the field, these courses have limited time to focus on helping students figure out who they are, where they want to go in life, and what they can do to get there. Consequently, the proseminar fills an important gap in professional socialization, while helping students see connections between their introductory coursework, these institutional services, and their goals.

\section{Best Practices for Structuring the Proseminar}

I spent considerable time thinking about the optimal order of course topics, striving to introduce information when it was most relevant and timely to students. In the first week, I focus on introducing students to the diversity of the field of Communication, using a set of central questions that animate research and teaching in our discipline. The second week is more philosophical, as I ask students to contemplate the purpose of college. They read an article on the financial value of obtaining a college degree and reflect on their reasons for pursuing further education. These online discussions help many students realize they have not given much thought to what they hope to get from their college experience, beyond attaining a degree. This realization helps them see the value of developing a compass for navigating the college years, based on their values and goals.

During the next few weeks, students learn more about the variety of majors offered in our department. I invite colleagues into class to talk about the major they affiliate with and the courses they teach. This segment helps students understand why courses are sequenced in a particular order and make more informed decisions when choosing their course electives. I also ask my colleagues to talk about what brought them to their specialty area, to illustrate how people find their professional path. As an added benefit, students get to meet most of the other instructors in the department. 
Alumni also play an essential role in this part of the course. I invite two or three alumni from each major to discuss a typical workday, share something from a project they are currently working on, and talk about which college courses and activities best prepared them to succeed in their current occupation. Almost everyone emphasizes the value of joining student clubs and organizations affiliated with one's major, such as the campus newspaper or Advertising Club. Alumni visitors also identify the most sought-after skills in their industries, encouraging students to seek out courses and experiences beyond the requirements for their major that could help them develop those skills.

Shortly before registration opens for the upcoming term, we spend a week talking about how advising works. Students learn about how advisors can help them select coursework, evaluate extracurricular opportunities, identify internships or study abroad opportunities, and improve their academic performance. Students also brainstorm questions to ask their advisors and form small groups to exchange ideas and refine these lists. Finally, students $\log$ into the online advising system to identify their advisor and schedule an appointment.

The next 2 weeks focus on opportunities to diversify one's skill set and develop the global mindset needed to succeed in an increasingly interconnected world (Javidan \& Walker, 2013). For this part of the course, I invite representatives of the five minors that are most popular with students in our departmentBusiness Administration, English, Hospitality Management, Psychology, and Visual Arts—-to pitch their programs to the class. We also discuss the demand for communication professionals who are fluent in more than one language (New American Economy, 2017). Next, we explore various study abroad opportunities, courses designed to improve intercultural competence, and steps for building a more diverse professional network.

We spend the final 2 weeks focusing on how to gain professional experience in one's chosen field, which has been identified as the number one attribute employers seek in college graduates (National Association of Colleges and Employers, 2017). I discuss how students can add valuable experience to their resumes through volunteering, and our department internship coordinator shares strategies for finding relevant internships. Students spend finals week reflecting on lessons learned during the semester and creating lists of the 10 most important things new students should know.

The course assignments are a weekly journal, a personalized plan of study, and a LinkedIn profile. In the weekly journal, students share challenges they are experiencing inside and outside of the classroom, a strategy recommended by instructional communication scholars studying the college transition experience (see Reynolds \& Sellnow, 2015). In the plan of study, students identify relevant course electives, possible minors, and global perspective opportunities. To foster more durable connections between incoming students, advanced students, and alumni visitors, students complete a LinkedIn assignment that requires them to create a professional profile, follow the department's page on this platform, and connect with peers and program graduates there. I also foster relationships by grouping students by their major or interest areas (e.g., work with non-profits, study abroad, volunteering, etc.) for class activities.

\section{Best Practices for Assessing the Proseminar}

In this section, I share results from assessments I conducted during the first semester we offered this proseminar, as a model for others to use. To measure the extent to which the course accelerated professional socialization, I asked students to complete a pretest survey during the first week of class and a posttest survey during finals week. I had 48 students enrolled in the course that semester 
(34 first-years, 11 sophomores, two juniors, and one senior). Of these 48 students, 43 completed the presurvey and 41 completed the post-survey.

I used t-tests to measure gains in peer network, faculty network, procedural knowledge, campus resource knowledge, extracurricular knowledge, occupational knowledge, and level of confidence in academic choices/abilities. Except for confidence in university choice, all gains were statistically significant. Table 1 presents a summary of the statistics, while I discuss each measure in turn below.

\begin{tabular}{|c|c|c|c|c|c|c|c|}
\hline \multirow[b]{2}{*}{ Assessment } & \multicolumn{2}{|c|}{ Pre-Test } & \multicolumn{2}{|c|}{ Post-Test } & \multirow[b]{2}{*}{$d f$} & \multirow[b]{2}{*}{$\boldsymbol{t}$} & \multirow[b]{2}{*}{$p$} \\
\hline & $M$ & $S D$ & $M$ & $S D$ & & & \\
\hline peer network & 0.70 & 1.09 & 2.59 & 2.38 & 79 & 4.569 & $<0.001^{* * *}$ \\
\hline knowledge of faculty & 1.05 & 1.34 & 3.17 & 1.87 & 80 & 5.906 & $<0.001^{* * *}$ \\
\hline extra-curricular organizations & 1.07 & 1.13 & 2.43 & 0.96 & 76 & 5.707 & $<0.001^{* * *}$ \\
\hline knowledge of career possibilities & 2.36 & 1.45 & 3.25 & 1.56 & 80 & 2.690 & $=0.0045^{* *}$ \\
\hline confidence in university choice & 4.29 & 1.02 & 4.34 & 0.82 & 81 & 0.270 & $=0.3925$ \\
\hline confidence in major choice & 3.92 & 1.05 & 4.29 & 0.81 & 81 & 1.768 & $=0.0404^{*}$ \\
\hline perceived self-efficacy & 3.79 & 1.00 & 4.37 & 0.54 & 81 & 3.280 & $<0.001^{* * *}$ \\
\hline
\end{tabular}

To measure strength of network, I asked students to identify-by name-peers and faculty members in their respective majors. At the start of the term, students could name less than one other student on average, with almost half (49\%) of the students stating that they did not know anyone else in their major. Knowledge of faculty at the start of the term was similar, with students able to name an average of one faculty member teaching in their major, and half unable to name anyone who would be teaching them. By the end of the semester, students could identify an average of 2.5 other students in their major by name, with the six who could not name someone stating that they knew several people by face rather than name. The average number of faculty that students could name increased to over three, with only two students (4\%) stating that they could not name any faculty member who taught courses in their major.

To assess institutional knowledge gains, I asked open-ended questions about scheduling advising appointments and which organizations we recommended for students in their major. The number of students who could identify the platform they should use to schedule a meeting with their advisor tripled between the pretest and posttest (from 18\% to 60\%). Most of the other students were able to describe how they would access the advising platform even if they could not identify it by name. The average number of major-relevant extracurricular organizations students could name increased from 1.07 to 2.43 , in line with the two to three organizations affiliated with each major. On a more anecdotal level, my colleagues reported higher levels of student preparation for advising meetings, while the leaders of our department's student organizations saw an increase in interest from first-year and sophomore students.

I also looked for changes in student understanding of career possibilities. The average number of career options students could identify went from an average of 2.36 , with $16 \%$ of students saying they did not know which careers were associated with their major, to 3.25, with only one student still unsure what he or she could do with the degree. Students also presented far more detailed explanations on the posttest than they did on the pretest (e.g., "working in agribusiness" versus "working as a press relations person 
for an ag company, writer for an ag magazine, 4-H extension agent, or event planning for a company"). These results indicate that students were able to identify more career possibilities and be more specific about those careers.

To measure confidence in academic choices and self-efficacy, I asked students to indicate their level of agreement with the following statements on a 5-point Likert scale:

- "I am confident I have chosen the right university."

- "I am confident I have chosen the right major."

- "I am confident in my ability to successfully navigate through my college career."

The pretest and posttest data show gains in confidence for all three areas. Confidence in major choice increased from 3.92 to 4.29 . Students demonstrated the greatest increase in perceived self-efficacy, from 3.79 to 4.37 . The gain in confidence for major selection also reflects a small number of students switching between the majors offered in our department after learning more about each one. I consider these early-in-college-career switches to be an additional benefit associated with the proseminar course. Confidence in university choice increased slightly, from 4.29 to 4.34 . In contrast to the other two measures of confidence, this gain was not statistically significant. This result may indicate that students entered college with higher confidence in their university choice compared to their major choice.

Course assessment was limited by the fact that students completed these surveys anonymously, which encouraged honest responses from working memory but prohibited paired-samples analysis. Future research on the impact of proseminar courses could include more qualitative measures that ask students to write about their college goals at various points throughout the semester. This type of data will help track the development of the integrative framework over time while revealing new areas for instructional intervention.

\section{Conclusion}

I believe the proseminar succeeded in accelerating students' professional socialization based on both the assessment and informal feedback on the course. The challenges I encountered were primarily administrative or logistical. While students benefit from meeting faculty and alumni, it was sometimes challenging to ensure that weekly objectives were met when I did not have full control over the lesson. In light of this challenge, I recommend that instructors spend time developing common goals with colleagues and alumni before they visit the class.

Our proseminar is a one-credit course meeting once a week, but it could be offered in different ways depending on department needs and resources. Those teaching an existing "introduction to the discipline" course could integrate proseminar content. Alternatively, departments could expand this course into a three-credit version, which would provide time for field trips to local workplaces, giving students a better sense of the careers they are considering. Ultimately, this proseminar can be adapted to accelerate socialization with any combination of the ideals and commitments that make our programs distinct communities of practice. 


\section{References}

Breslin, J. D., \& Sharpe, A. (2018). Transformative learning in the first-year experience. In M. G. Strawser (Ed.), Transformative student experiences in higher education: Meeting the needs of the twenty-first century student and modern workplace (pp. 207-223). Lexington Books.

Conley, D. T. (2008). College knowledge: What it really takes for students to succeed and what we can do to get them ready. Jossey-Bass.

Javidan, M., \& Walker, J. L. (2013). Developing your global mindset: The handbook for successful global leaders. Beaver's Pond Press.

Martin, J. M. (2011). What now? What next? A narrative analysis of cross-cultural adaptation and college student retention. (Doctoral dissertation). https://web.archive.org/save/https://uknowledge.uky. edu/gradschool_diss/179/

Miller, V. D., \& Jablin, F. M. (1991). Information seeking during organizational entry: Influences, tactics, and a model of the process. Academy of Management Review, 16(1), 92-120. https://doi.org/10.5465/ AMR.1991.4278997

National Association of Colleges and Employers. (2017). Employers prefer candidates with work experience. https://web.archive.org/save/https://www.naceweb.org/talent-acquisition/candidate-selection/ employers-prefer-candidates-with-work-experience/

National Survey of Student Engagement. (2018). Engagement insights: Survey findings on the quality of undergraduate education. Indiana University Center for Postsecondary Research. https://web. archive.org/save/http://nsse.indiana.edu/pdf/NSSE_Annual_Results_2018.pdf

New American Economy. (2017). Not lost in translation: The growing importance of foreign language skills in the U.S. job market. https://web.archive.org/save/http://www.newamericaneconomy.org/wpcontent/uploads/2017/03/NAE_Bilingual_V9.pdf

O'Keeffe, P. (2013). A sense of belonging: Improving student retention. College Student Journal, 47(4), 605-613. https://web.archive.org/save/https://www.ingentaconnect.com/contentone/prin/ csj/2013/00000047/00000004/art00005

Reynolds, M., \& Sellnow, D. (2015). Navigating the new: Examining the transition experiences of firstsemester college students. In T. Hicks and C. W. Lewis (Eds). High school to college transition research studies (pp. 3-25). University Press of America.

Smith, A., Carmack, H., \& Titsworth, B. (2006). Managing the tension of in(ter) dependence: Communication and the socialization of first-year college students. Journal of The First-Year Experience \& Students in Transition, 18(2), 83-109. https://web.archive.org/save/https://sc.edu/about/offices_and_ divisions/national_resource_center/publications/search/details.php?id=2158

Sollitto, M., Johnson, Z. D., \& Myers, S. A. (2013). Students' perceptions of college classroom connectedness, assimilation, and peer relationships. Communication Education, 62(3), 318-331. https://doi. org/10.1080/03634523.2013.788726

U.S. Department of Education. (2017). Beginning college students who change their majors within 3 years of enrollment. https://web.archive.org/save/https://nces.ed.gov/pubs2018/2018434.pdf

Weidman, J. C., \& Stein, E. L. (2003). Socialization of doctoral students to academic norms. Research in Higher Education, 44(6), 641-656. https://doi.org/10.1023/A:1026123508335 